\title{
Relationship between consumer behavior and success of urban agriculture
}

\begin{abstract}
.
Consumers prefer locally grown food products. One source that provides local food is urban agriculture, the farming in and around cities. A number of urban farmers is selling their products directly to consumers. In addition, consumers have the option to grow their own food on certain urban farms. Given this, we investigate how likely consumers are to purchase or grow their own food at urban farms and what determines this likelihood. Given that millennials are a key stakeholder of sustainable consumption and those with the greatest increase in numbers of food gardeners, we conducted an online survey with over 300 Generation Y respondents. We investigate whether young consumers perceive the health impacts and environmental benefits provided by urban agriculture, and what attitudes they hold towards this source of produce. Empirical results show that both psychological and personal factors affect consumer intentions to participate in urban agriculture. Among others, subjective knowledge regarding urban agriculture and a generally favorable attitude toward urban farms increases the likelihood to buy and grow produce at urban farms. Female and older consumers are more likely to grow their own produce. These findings can be used by stakeholders in urban agriculture to design target-oriented marketing activities.
\end{abstract}

\section{Key words.}

Attitudes; community garden; Generation Y; local food; Millennials; subjective knowledge; perception 


\section{Introduction}

Consumer demand for local food continues to grow (e.g., Thilmany et al., 2008; Adams and Salois, 2010; Grebitus et al., 2013a; Meas et al., 2014; Feldmann and Hamm, 2015; Pyburn et al., 2016). By 2014 local food sales in the U.S. reached about $\$ 12$ billion with an expected increase to $\$ 20$ billion by the year 2019 (USDA, 2016a). In response to this, housing development builders and cities started to incorporate local food production and points of sale into new and established communities (Hughes and Boys, 2015), catering to the approximately 82 percent of the population in the United States who are living in urban areas (World Bank, 2016 ${ }^{1}$.

The practice of "growing, processing, and distributing of food and other products through intensive plant cultivation and animal husbandry in and around cities" is called urban agriculture $^{2}$ (Bailkey and Nasr, 1999). Regarding the distribution of food, about 8\% or 163,675 of all U.S. farms sell their food using direct-to-consumer marketing (e.g., farmers' markets, roadside stands, directly to restaurants), with $70 \%$ out of the $8 \%$ selling their food exclusively using such channels, e.g., CSAs (ERS, 2015). These producers are competing with national grocers such as Whole Foods and Kroger, who are partnering with local farmers to offer products at their stores that are grown within the state lines. For example, Walmart sources $20 \%$ of fresh fruits and vegetables in-state and Wegmans sells $30 \%$ of locally grown produce (King et al., 2010). It follows that urban farmers, who choose to sell directly, need to understand what drives consumers to purchase produce at the farm in order to effectively and efficiently market their products.

\footnotetext{
${ }^{1}$ http://data.worldbank.org/indicator/SP.URB.TOTL.IN.ZS, last access 1/15/2017.

${ }^{2}$ According to the FAO (2007) "urban agriculture (UA) is a dynamic concept that comprises a variety of livelihood systems ranging from subsistence production and processing at the household level to more commercialized agriculture. It takes place in different locations and under varying socioeconomic conditions and political regimes (FAO, 2007, p. V).”
} 
Knowing more about key drivers might also enable stakeholders to increase the share of citizens that take part in urban agriculture. This is valuable because urban agriculture provides a number of additional benefits, such as, contributing to food security, supporting healthy dietary patterns (e.g., Warren et al., 2015; Zezza and Tasciotti, 2010), and improving local ecology and sustainability (e.g., Wakefield et al., 2007). Given these benefits, it seems of interest not only from a business standpoint but also from a societal standpoint to further investigate underlying reasons that drive individuals to participate in urban agriculture.

Previous literature on participation in urban agriculture has mainly focused on developing countries. For example, Warren et al. (2015) provide a comprehensive review of the literature that investigates the relationship between urban agriculture and nutrition (food security, nutrition status and variety). Studies referring to developed countries investigated the social missions of urban agriculture focusing on the urban farms, i.e., growers (Dimitri et al., 2016), assessed the needs of urban farmers who face limited resources (Surls et al., 2014), and analyzed the impact of community gardens on communities using mainly exploratory methods (e.g., Armstrong, 2000; Firth et al., 2011; Wakefield et al., 2007). Hence, there seems to be a gap in the literature regarding quantitative research in developed countries that focuses on the urban agriculture consumer. We aim to extend the literature by analyzing consumer behavior as it relates to urban agriculture as an outlet for food.

The objective of our study is to evaluate success factors of urban agriculture participation. In this regard, we focus particularly on the future consumer, the Generation Y. As pointed out by Hume (2010), one key stakeholder group of sustainable behavior is comprised of young consumers, the Generation Y or Millennials. This generation is not only educated, but also environmentally aware without actively behaving in a pro-environmental manner. They seem to 
be compassionate but not willing to act upon it (McCrindle, 2007). It follows, that we need to investigate what affects their behavior in order to develop strategies that encourage them to put their beliefs into action.

In order to analyze how urban farms can be successful, it is important to understand determinants of consumer behavior that are likely to influence shopper habits, when it comes to produce purchase behavior. Behavioral concepts, such as, perception, subjective knowledge and attitudes, play an important role for purchase decision making (e.g., Howard and Sheth, 1969). To start with, consumers have to be able to perceive urban agriculture as a viable source of produce. In this regard, making them aware that urban farms are a source for local food can lead to positive perception, given that purchasing foods from urban farms provides firsthand knowledge on the origin of the products and truly is locally produced food. Apart from the perception, consumers need to be knowledgeable about urban farms. Without having any knowledge about urban agriculture, as a potential source of local produce and other benefits associated with it, consumers are hypothesized to be less likely to purchase produce from an urban farm. Furthermore, consumers need to hold positive attitudes towards urban agriculture in order to actually make a purchase. This leads to the following research questions:

1. How do consumers perceive urban agriculture?

2. Do consumers feel knowledgeable when it comes to urban agriculture?

3. Do consumers hold positive attitudes towards urban agriculture?

4. Are consumers likely to buy produce from an urban farm, and how is this influenced by behavioral aspects?

In addition to urban farms serving as a point of sale for local produce, they also offer citizens the opportunity to grow their own food. When individuals actively participate in growing 
their own food at the urban farm, they are likely to experience an improvement in health and their communities are more developed (e.g., Wakefield et al., 2007). For example, community gardens promote physical, mental and social health as they, among others, restore attention, reduce stress, evoke positive emotions and lead to social integration (Abraham et al., 2010). This suggests that growing their own food may improve their lifestyle by being more physically active and mentally and emotionally relaxed. Similarly, community gardening promotes social health and community cohesion in form of stable relationships, which also contributes to a healthy lifestyle (Wakefield et al. 2007; Abraham et al., 2010). This is important, given the increase in obesity and sedentary lifestyles, particularly in children and young adults (e.g., Caballero, 2007; Sahoo et al., 2015). Therefore, gardening, i.e., growing food, can play a part in improving one's wellbeing. In addition to the physical component of gardening, nutrition education by means of learning about food production and processing comes more naturally when growing food. At the same time, growing produce encourages fruit and vegetable consumption, since it familiarizes the growers with the foods that might be less present otherwise (Libman, 2007). In general, an improved access to food and nutrition is related to community gardens (Wakefield et al. 2007). This leads to the final research question:

5. Are consumers likely to grow their own produce, and how is this influenced by behavioral aspects?

As pointed out above, we focus on Generation Y because Millennials are a key stakeholder of sustainable consumption (Hume, 2010). Furthermore, they account for the greatest increase in numbers of food gardeners (NGA, 2014). Hence, understanding the behavior of Millennials towards urban agriculture, in other words investigating the determinants of 
purchasing food at an urban farm or growing food at an urban farm, promises insight into longterm success factors of urban agriculture.

Against this background, the aim of this study is to investigate the impact of consumer perception, knowledge and attitudes towards the likelihood to purchase produce from urban farms and the likelihood to grow their own produce at urban farms. Figure 1 displays this relationship between the questions:

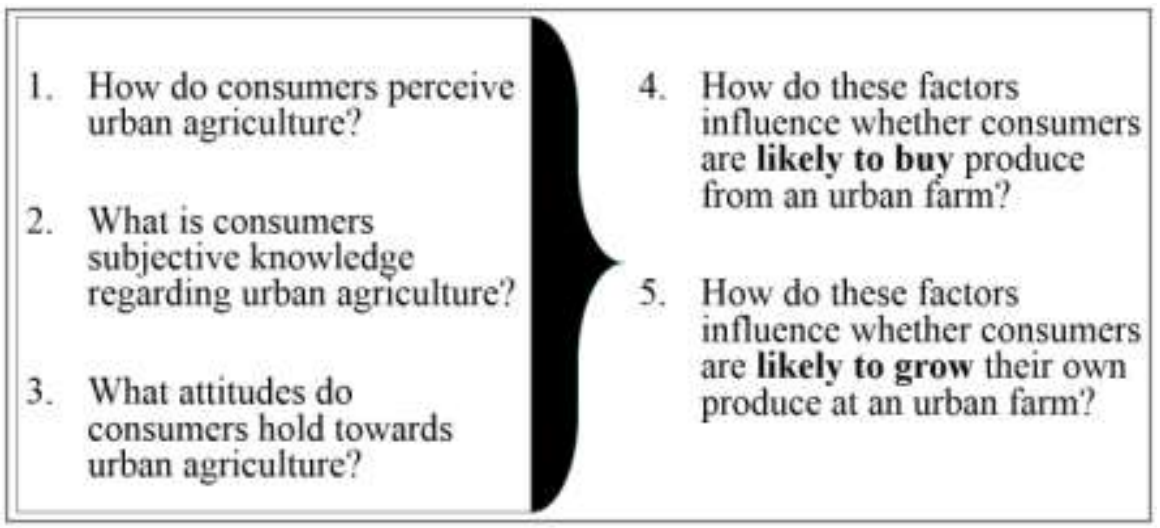

\section{Figure 1: Research framework}

\section{Conceptual framework}

In order to answer our research questions we apply Howard and Sheth's (1969) theory of buyer behavior. The authors state that stimuly, perceptual constructs and learning constructs, lead to the outputs of attention, comprehension, attitudes, intention and ultimately purchase behavior. According to Howard and Sheth (1969), attention influences comprehension, which impacts attitudes, which affects intention and then purchase behavior. In this regard, attention is a necessity for perception (Orquin and Mueller Loose, 2013). Given that Kroeber-Riel and Weinberg (2003) show that perception influences related product evaluation and purchase decision making, and considering that Shapiro (1970) links perceived quality to purchase 
likelihood, we apply the concept of perception, rather than attention, in our study, and refer to purchase likelihood as final concept, rather than considering the actual purchase decision. Comprehension can be reflected by its synonym knowledge. In this regard, multiple frameworks (e.g., Ajzen, 1991) have shown that attitudes and knowledge determine intention, which can be expressed as likelihood of purchase.

Taking these theories into account, we arrive at a conceptual model that serves as foundation for our research. We address the influence of the psychological constructs perception, knowledge and attitudes on both, the likelihood to purchase produce from and the likelihood to grow produce at urban farms. We also include personal factors as determinants of this likelihood based on Steenkamp (1989). Steenkamp (1989) displays in his conceptual model of quality perception the influence of personal factors on perceived quality and it seems reasonable to assume a similar influence of several personal factors on intentions, i.e., purchase and growing likelihood. Hence, as figure 2 shows, we distinguish between psychological and personal factors, as determinants of consumer behavior related to urban agriculture.

In the following, we will provide the theoretical background on the psychological constructs and will discuss related empirical findings. Afterwards, we will discuss the methods used to measure the respective constructs and factors. Specifically, we use mixed methods research with the approach of concurrent nested research, conducting one data collection with a predominantly quantitative approach but also including a qualitatitve data collection (FoodRisC, 2017). While the qualitative data regards perception, the quantitative data regard knowledge, attitudes, socio-demographics, produce purchase frequency and intentions. Though we do not mix the data in a traditional way during the analysis (e.g., including the perception data in the bivariate ordered probit model used to determine what affects the intention), the design allows 
for a deeper insight towards success factors of consumer behavior as it relates to urban agriculture.

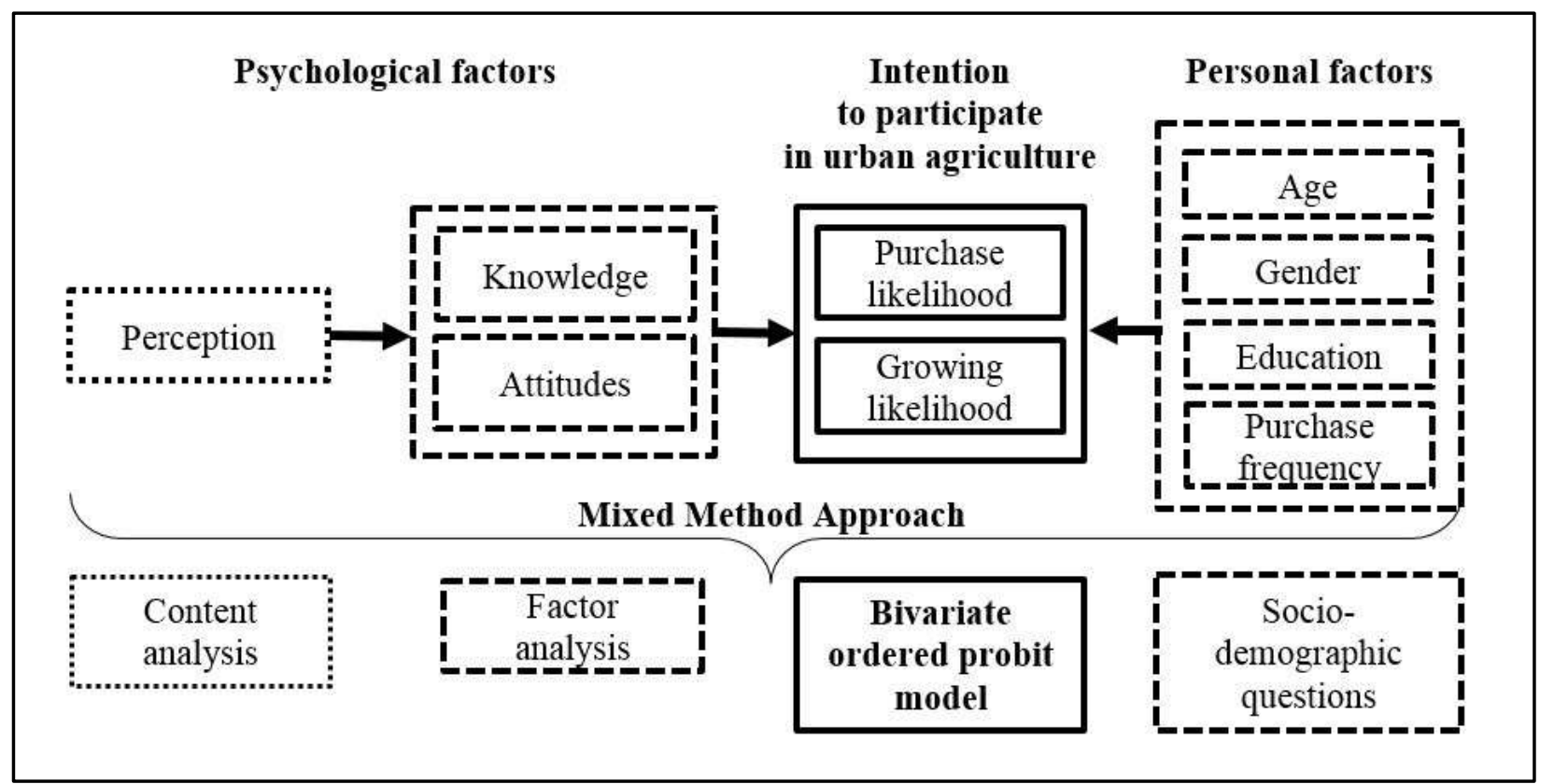

\section{Figure 2: Conceptual framework}

Note: The factors in the dashed boxes are hypothesized to affect the intentions displayed in the solid boxes. Dotted boxes display the qualitative approach, lined boxes display the quantitative approach.

\section{Theoretical background and previous literature}

\section{Perception}

Every product makes an impression on the consumer, which can be understood as perception, where consumers gather, organize and subsequently evaluate product information. This impression is then combined with prior experiences as well as experiences made during and after the shopping occasion (Gryna, 1998). These experiences include characteristics of the product itself, the shopper and the shopping location. Depending on the perception process, the importance of certain characteristics can vary in that some consumers prefer convenience and cheaper prices, while others favor specific ambience and assortments of products. Moreover, 
each consumer differs in how they personally perceive products and retail outlets, which depends on their abilities, preferences and experiences (Grebitus, 2008). Based on this background, the shopping outlet might affect perception through the intended use and / or situational factors, such as, convenience (Oude Ophuis and van Trijp, 1995). Hence, in order to evaluate success of urban agriculture, it is important to investigate whether consumers perceive urban farms as a possible point of sale and whether they consider food from urban farms to be local. Consumer perception of what food qualifies as local is of particular interest, since that results in higher willingness to pay. For example, previous studies found that consumers have a higher willingness to pay for local compared to organic apples (Costanigro et al., 2011), and for local compared to organic and GMO-Free potatoes (Loureiro and Hine, 2002). In addition, consumers are willing to pay more for locally grown Gala apples and red round tomatoes, compared to domestic but not local, and imported apples and tomatoes (Onozaka and Mcfadden, 2011). The preferences for locally grown food even extend to ingredients. This was shown by Meas et al. (2014) for local versus organic blackberry jam, and by James et al. (2009) for local versus USDA organic, low fat, or no sugar added applesauce. For a comprehensive review on local food perception and preferences see Feldmann and Hamm (2015). In this study, we analyze consumer perception of urban agriculture to determine whether they would consider it a viable source of produce. Since the perception affects the purchase behavior, it will be an important factor in assessing future success of urban agriculture.

\section{Subjective knowledge}

There are distinct categories of consumer knowledge that affect consumer behavior: subjective knowledge and objective knowledge as well as prior experience, i.e., usage experience (Brucks, 1985; Raju et al. 1995). Subjective knowledge has been acquired by direct experience and is 
interpreted by the experiencer. It is also known as perceived knowledge because it reflects what consumers think they know about a subject as opposed to what they actually, objectively know (Carlson et al., 2009; Raju et al., 1995). An example with regards to urban agriculture would be that consumers often believe urban farmers to use organic practices and the food to be more natural even though this does not have to be true. This would be a case of subjective rather than objective knowledge. Previous literature suggests that subjective knowledge impacts consumer behavior. For example, using latent class analysis for data from a Canadian and a German consumer survey for beef and potatotes, Peschel et al. (2016) demonstrate the relationship between subjective knowledge and consumer choice of food labeled for carbon and water footprints. Conducting focus group interviews on purchasing and disposal habits, Ellen (1994) provides evidence of the impact subjective knowledge has on precycling and recycling choices and behaviors. Applying a probit model and an analysis of variance to a convenience sample, Aertsens et al. (2011) show how subjective knowledge influences consumer attitudes and motivations towards organic food and its consumption. Furthermore, subjective knowledge can determine the quality of consumer decisions (Moorman et al., 2004). Therefore, we study consumers' subjective knowledge regarding urban agriculture and attempt to determine the relationship between this type of knowledge and the likelihood of urban farms to become a viable source of produce.

\section{Attitudes}

Attitudes are consumer evaluations of a psychological entity. They are formed through beliefs about the probability of consequences depending on behavior and assessments of how good or bad those consequences would be if they became a reality (Trafimow and Finlay, 2002; Ajzen, 1991). When attitudes are strong enough, they impact purchase behaviour (Trommsdorff, 2003). 
For example, this was documented when consumers started to increasingly purchase local foods instead of organic foods, displaying a shift in preferences from organic to local foods in the late 1990s (Gallons et al., 1997; Food Processing Center, 2001). Research in the 1990s showed that $86 \%$ of consumers considered it an advantage and held a positive attitude toward purchasing locally grown food (Bruhn et al., 1992). Also, a survey in the early 2000s, indicated that almost all surveyed consumers (99\%) had recently purchased locally grown food (Food Processing Center, 2001). With this research, we determine what attitudes consumers are holding towards urban agriculture. This is then used to inform on the opportunity for urban agriculture to successfully serve as an outlet for produce. Since attitudes shape consumer shopping behavior, this needs to be addressed when considering urban agriculture as point of sale for produce.

\section{Methodology}

\section{Design of the study}

We conducted an IRB approved online survey with $n=325$ individuals in fall 2015. Participants were recruited from a 400-level class at Arizona State University in the U.S. All respondents received five points towards the final exam (equivalent to one percent of the final grade) as credit for their participation. We used a student sample because when it comes to sustainable behavior, young consumers (Generation Y) are a key stakeholder group (Hume, 2010). These young consumers are making up a great share of total consumption expenditure in developed countries (Bentley et al., 2004), such as the U.S. They are the future public (Smola and Sutton, 2002). Therefore, it is of importance to consider their behavior, particularly when it concerns purchase decision making and consumption that can be understood to be more sustainable. Furthermore, given that we are also researching the intention to grow food, this age group is of interest 
because data from the National Gardening Association (NGA) show that millennials have the largest increase in the number of gardeners compared to other age categories. About 13 million millennials were growing food in 2013 spending $\$ 1.192$ billion (NGA, 2014). Hence, we focus on upper division undergraduate students that fit the profile of young consumers described as informed, knowledgeable (Heaney, 2006) and most educated (McCrindle, 2007; Hume, 2010). Specifically, the sample consisted of $38 \%$ female and $62 \%$ male respondents. This is lower than the share of adult females in Arizona, which accounts for 50\% (Census, 2015). The median age of participants is 22 years $(M=23 ; S D=4.4)$ ranging from 20 years to 61 years, which is younger than the median age of 34 years (Census, 2015). The education level of the sample ranges from high school diploma (20\%), to some college experience (62\%), to technical school diploma (2\%) to Bachelor's Degree (16\%), while $86 \%$ of Arizonans are a high school graduate or higher (note this accounts for persons age 25 years+) and $28 \%$ of Arizonans hold a Bachelor's degree or higher (again for persons age 25 years+) (Census, 2015). Given the current statistics a direct comparison, however, is not sensible for education. About 55\% of the interviewees have an income lower than $\$ 50,000$ annually before taxes, this is comparable to the median household income in Arizona which amounts to $\$ 50,255$ (Census, 2015). Some $6 \%$ of respondents had children in the household ( $\mathrm{SD}=0.25)$, with an average household size of $3.2(\mathrm{SD}=1.29)$ persons, which is slightly higher than the household size for Arizona of 2.69 (Census, 2015). Overall, differences between the sample and the general population are to be expected, given that we purposely surveyed millennials. In the following gender, age and education are included in the bivariate ordered probit as independent variables to test the effect of personal factors on intentions towards urban agriculture. 


\section{Measuring perception}

In order to measure how consumers perceive urban agriculture, we used free elicitation technique (e.g., Grebitus, 2008). Results from free elicitation technique encompass consumers' stored (prior) information, i.e., cognitive structures, with regards to a certain knowledge area as well as related perceptions or misperceptions. Free elicitation technique is an appropriate method to survey consumer perception (Van Kleef et al., 2005; Kanwar et al., 1981; Olson and Muderrisoglu, 1979). The technique is understood as a non-structured form of questioning, where participants are asked to write down their first thoughts when being presented with a key stimulus (Parasuraman, 1990). The research subjects can express anything they think of when seeing the stimulus.

In applying the method, we follow Olson and Muderrisoglu's (1979) and Roininen et al.'s (2006) technique. While in previous studies participants were at times limited to the number of associations to be written down, our respondents were asked to write down everything that comes to mind when thinking of community gardens / urban farming. We used both stimuli to analyze perception of urban agriculture because urban agriculture entails, among others, community gardening and farms located in metropolitan areas (USDA, 2016 ${ }^{3}$; U. of California, $\left.2016^{4}\right)$

The data collected was analyzed by means of content analysis (Mayring, 2000). This analysis allows to make assumptions, and investigates the intent and motivation regarding a certain topic in a formal way using a specific content observed (Stempel, 1981; Hsia, 1988). Content analysis is utilized by applying quantitative measures that investigate the data source in

\footnotetext{
${ }^{3}$ https://www.nal.usda.gov/afsic/urban-agriculture, last accessed 1/16/2017.

${ }^{4} \mathrm{http}: / /$ ucanr.edu/sites/UrbanAg/What_is_Urban_Agriculture/, last accessed 1/16/2017.
} 
question in an objective and systematic way. When using this analysis, a so-called universe is defined which serves as information source. Next, a unit is identified for the universe, determining which information to count (Hsia, 1988; Wimmer and Dominick, 1983; Stempel, 1981). Since we apply content analysis to free elicitation technique data, our units are the single words or sentences written down by participants.

In order to provide meaning to the units, we classified the content provided into categories that are used for investigation. This provides a framework for analyzing within the determined context, here urban agriculture. All associations provided by participants regarding the key stimulus are organized, categorized and then added up into frequencies (Lamnek, 1995; Bonato, 1990). The categories are the key of the actual analysis to be used for further exploration of the topic (Wimmer and Dominick, 1983), and need to be closely related to the study's research questions in a theoretical way. Furthermore, these categories need to be reliable, practical, comprehensive and mutually exclusive (Stempel, 1981; Wimmer and Dominick, 1983). In this article we use the three pillars of sustainability (e.g., Krajnc and Glavič, 2005): Economy, Society and Environment, as three categories. In addition, we include Food and Food Attributes, Point of Sale and Others as categories based on results of an analysis of food quality by Grebitus (2008). These categories seem appropriate to categorize the data into groups meaningful for urban agriculture.

\section{Measuring subjective knowledge}

In order to measure subjective knowledge, we asked respondents how informed they feel towards the more general aspect of sustainability given that urban agriculture "can make important contributions to social, economic and ecological objectives of sustainable urban development" (FAO, 2007, p. V). In addition, we inquired towards subjective knowledge on community 
gardens, Community Supported Agriculture, urban gardens and urban agriculture. We used these terms as they are among the many examples of urban agriculture (community gardening in vacant lots and parks, community supported agriculture based in urban areas, family farms located in metropolitan greenbelts, etc.) (USDA, $2016^{4}$; U. of California, 2016 $)$. To evaluate the subjective knowledge, we followed Grebitus et al. (2013b) using a scale ranging from $1=$ no knowledge to $5=$ very knowledgeable. We include the values for sustainability of food supply as independent variable in the following econometric analysis. We use the four specific measures for urban agriculture by creating an index for each respondent, summing up the individual items into one "urban agriculture subjective knowledge" measure (e.g., Flynn and Goldsmith, 1999; Peschel et al., 2016). After eliciting subjective knowledge we provided a definition on urban agriculture to assure that all participants have sufficient information on the term for the remainder of the survey.

\section{Measuring attitudes}

In order to analyze consumers' attitudes towards urban agriculture we used two sets of questions. The first set considered general attitudes towards urban farms. The second set measured attitudes towards factors that encourage and prevent purchases at urban farms.

Specifically, in the first set respondents received multiple questions to identify what attitudes drive consumers when it comes to participating in urban agriculture via purchasing and growing produce at an urban farm. The questions were answered individually and took those attitude-dimensions relevant for assessing urban agriculture success into account. The questions stem mainly from the Community Food Project Evaluation Toolkit (National Research Center,

\footnotetext{
${ }^{4}$ https://www.nal.usda.gov/afsic/urban-agriculture, last accessed 1/16/2017.

${ }^{4} \mathrm{http}: / / \mathrm{ucanr} . e d u /$ sites/UrbanAg/What_is_Urban_Agriculture/, last accessed 1/16/2017.
} 
Inc., 2006). Several questions pointed towards "Because I visit $\{$ this market $\}$, I now..." (page 106). Additional questions pointed towards "Because I work in \{this garden\}..." (page 143). In order to fit our survey, we slightly rephrased the original questions, e.g., from "I have learned more about gardening" to "Urban gardens help you learn more about gardening." We applied a 5-point Likert scale from $1=$ completely disagree to $5=$ completely agree to all questions. We then employed exploratory factor analysis to the data. Specifically, we used principal component analysis with varimax as rotational strategy to determine the number of factors. This allowed us to analyze more or less highly correlated items, and enabled us to reduce the attribute space from a larger number of more or less highly correlated individual variables into a select number of unrelated and independent factors. In doing so, a latent structure of the variables was uncovered. To quantify the reliability of the generated factors Cronbach's alpha was used for each factor, which should be greater than 0.5 to be able to include the respective factor in the following analysis (Kim and Mueller, 1978; Hair et al., 1998).

In the second set of questions respondents evaluated a number of reasons that consumers can consider as encouraging or preventing them from purchasing food at urban farms on a scale from 1 (prevent) to 5 (encourage). We then created two indexes by using the median to determine which items should be combined into the "encourage" index (sum of values above the median divided by the number of values) and which items should be combined into the "prevent" index (sum of values equal to and below the median divided by the number of values). The items also stem from the Community Food Project Evaluation Toolkit (National Research Center, Inc., 2006, pages 106, 138, 143, 284) as well as from Pan and Zinkhan (2006), Wakefield et al. (2007), Grebitus et al. (2013a), and Nilsson et al. (2015). 


\section{Bivariate ordered probit model}

Consumers' likelihood to purchase produce from an urban farm and their likelihood to grow their own produce at an urban farm are expressed as different likelihood categories on a seven-point Likert scale, where 1 stands for "very unlikely" and 7 is "very likely." The likelihood categories are used to measure the corresponding latent utilities. In the survey, the dependent variables are categorical, specifically very unlikely, unlikely, somewhat unlikely, undecided, somewhat likely, likely, very likely. Hence, we estimate a bivariate ordered probit model to find the determinants of the likelihood to purchase from or grow produce at an urban farm at the same time.

We make use of a bivariate ordered probit model that can be derived from a latent variable model (see Sajaia, n.d.). Technically, the univariate ordered probit model can be extended to the bivariate ordered probit model. In a univariate ordered probit model, the unobserved likelihood for purchasing, i.e., growing produce at an urban farm, is:

$$
y_{i}^{*}=\beta x_{i}+\varepsilon_{i}
$$

where $y_{i}^{*}$ is the unobserved latent and continuous likelihood to purchase/grow produce; $\beta$ is a vector of parameters to be estimated; $x_{i}$ is the vector of independent variables; $\varepsilon_{i}$ is a random error term that follows a standard normal distribution. The likelihood is "latent", since we observe an indicator of the preferred level of being willing to purchase or grow the produce, but not the actual behavior itself. In our case, the likelihood to purchase/grow are the observed discrete categories, which are denoted as $y_{i}$

$$
y_{i}=\left\{\begin{array}{cc}
1 & y_{i}^{*} \leq u_{1} \\
2 & u_{1}<y_{i}^{*} \leq u_{2} \\
\vdots & \\
J & y_{i}^{*}>u_{J}
\end{array}\right.
$$


where $u_{i}$ 's are unknown cut-off values of the latent willingness to purchase/grow which will be estimated; $J$ is the number of frequency categories. As stated above, we had seven categories ( $1=$ very unlikely, $2=$ =unlikely, $3=$ somewhat unlikely, $4=$ =undecided, 5=somewhat likely, $6=$ likely, $7=$ very likely), therefore, $J=7$. We assume the error term has a standard normal distribution. We follow Sajaia's (n.d.) specification of the simultaneous bivariate ordered probit model. For related STATA code as well as specification of the model the interested reader is referred to Sajaia (n.d.).

\section{Empirical results}

\section{Purchase frequency of local produce}

Considering the importance of local food overall and the fact that urban farms can serve as suppliers for local food, we measured how often participants purchase local produce. This can provide information on whether current local purchase frequency could lead to using urban farms as outlet for the food. We measured this on a seven-point scale from never to daily. Results show that $1.5 \%$ purchase it daily, $9 \%$ shop for it $2-3$ times a week and $16 \%$ buy local once a week. A total of $21 \%$ indicated local purchases $2-3$ times a month, $16 \%$ buy it once a month and the majority of $27 \%$ shops for local food less than once a month. About $10 \%$ never buy local produce. Given that the majority of the sample purchases local food at least once a month this seems promising for urban farms. The purchase frequency of local food is included in the bivariate ordered probit model as independent variable as per our conceptual framework. 


\section{Perception of urban agriculture}

Next, we discuss the descriptive findings for the psychological factors displayed in our conceptual framework. We start with the qualitative part of the data collection, where we applied free elicitation technique to measure consumers' perception regarding urban agriculture. Our results show that the participants mentioned a total of 478 different concepts, including both single terms (e.g., healthy, fresh) and whole phrases (e.g., "A place where people share something like a plot of land to grow items they are interested in eating."). The concepts were grouped into the six categories, Economy, Society, Environment, Food \& Food Attributes, Point of Sale and Other, shown in table 1. Results indicate that consumers primarily associate specific "food \& food attributes" with urban farms followed by the two categories, "economy" and "society". The category "environment" ranks fourth.

Table 1: Content categories related to urban agriculture

\begin{tabular}{lrr}
\hline Category & Count & \% of total \\
\hline Economy & 78 & $16 \%$ \\
Society & 78 & $16 \%$ \\
Environment & 73 & $15 \%$ \\
Food \& Food Attributes & 181 & $38 \%$ \\
Point of Sale & 29 & $6 \%$ \\
Other & 39 & $8 \%$ \\
Total & 478 & $100 \%$ \\
\hline
\end{tabular}

Tables $2 \mathrm{a}$ and $2 \mathrm{~b}$ show the associations organized in categories. In order to reduce the large number of associations, they were merged based on similarity. For example, "healthy", "health" and "healthier" were combined into "healthy". Overall, the findings show that consumers think of, e.g., fresh, healthy, local and organic. They also feel that "life is still fine" and associate earth-friendly and sustainability with urban agriculture, which can be understood as an 
environmental component. Furthermore, they think of social issues such as "helping local communities," and "bringing people together." In addition, they point out the economic perspective displaying contrary opinions of "better quality but more expensive" versus "high prices for little marginal benefit" indicating that not all consumers may be in favor of urban agriculture, and may require additional education. However, negative aspects such as inconvenience and "a waste of time and energy" are also present in the responses.

Specifically, the category "economy" is dominated by associations with urban agriculture being expensive and of higher cost (30\% of category associations), farms/farming in urban areas (22\% of category associations) and the local economy (17\% of category associations). The majority thinks urban agriculture is expensive, whereas some believe it to be cheap and cost saving. The category "society" is dominated by the associations with positive community building ( $21 \%$ of category associations), helping and supporting the local economy (13\% of category associations) and the idea that the community would have access to growing produce (11\% of category associations). While the majority thinks urban agriculture will have a positive effect on the local community, others critically note that it might be challenging to involve community members. The category "environment" is dominated by the associations earth friendliness and sustainability (38\% of category associations), alternative gardening systems (14\% of category associations) and the mention of green initiatives (12\% of category associations). While the majority thinks urban agriculture will have a positive effect on the environment, it is mentioned that, even though it is a great idea, it will be difficult to realize.

The category "food and food attributes" is dominated by the associations organic (19\% of category associations), healthy (17\% of category associations) and the mention of certain produce (13\% of category associations). 
Table 2a: Perception of urban agriculture (community gardens/ urban farming) Part 1

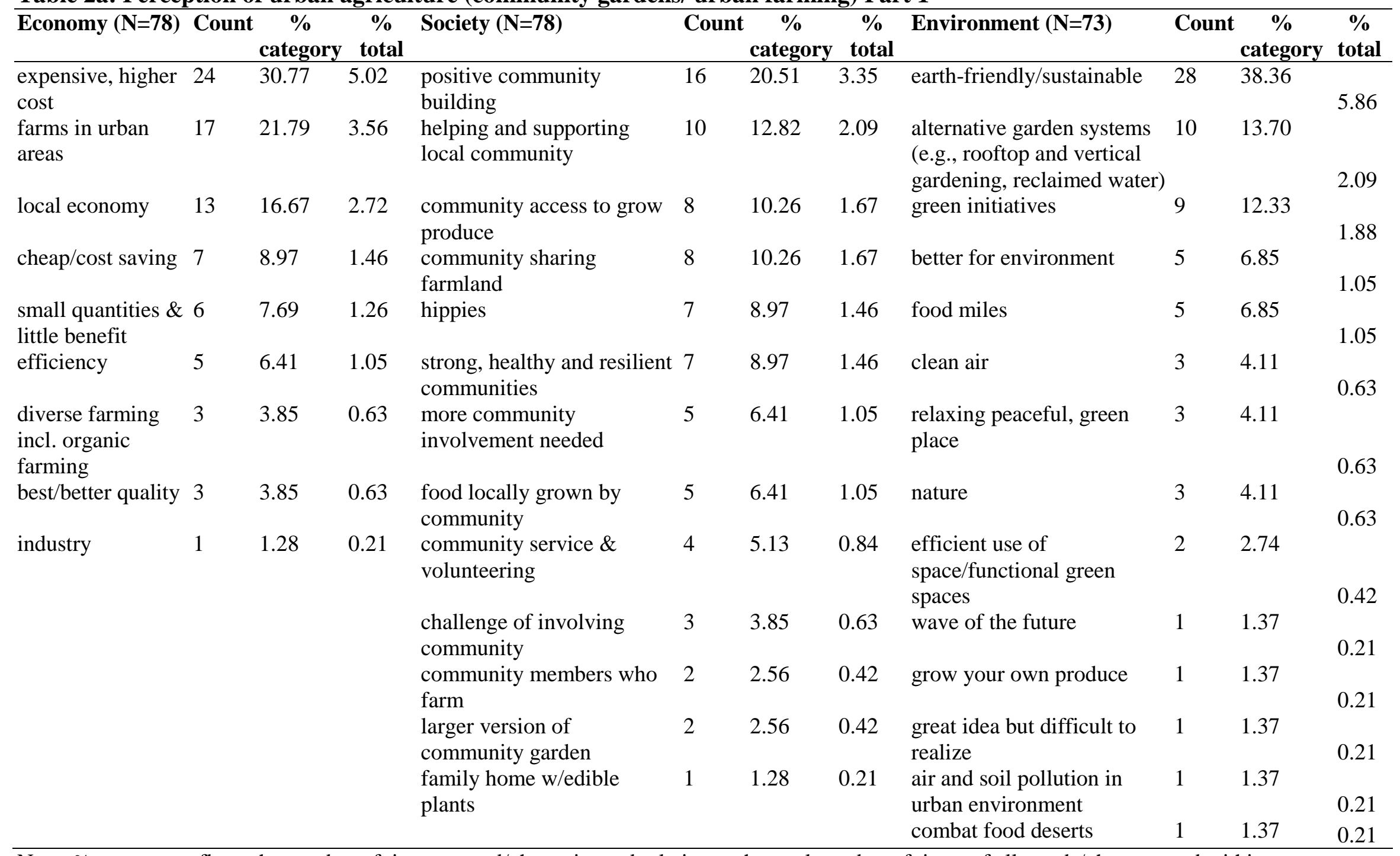

Note: \% category reflects the number of times a word/phrase is used relative to the total number of times of all words/phrases used within a content category. \% total reflects the number of times a word/phrase is used relative to the total number (sum) of all responses (=478). 
Table 2b: Perception of urban agriculture (community gardens/ urban farming) Part 2

\begin{tabular}{|c|c|c|c|c|c|c|c|c|c|c|c|}
\hline $\begin{array}{l}\text { Food \& Attributes } \\
(\mathrm{N}=181)\end{array}$ & Count & $\begin{array}{c}\% \\
\text { category }\end{array}$ & $\begin{array}{c}\% \\
\text { total }\end{array}$ & Point of Sale $(\mathrm{N}=29)$ & Count & $\begin{array}{c}\% \\
\text { category }\end{array}$ & $\begin{array}{c}\% \\
\text { total }\end{array}$ & Other $(\mathrm{N}=39)$ & Count & $\begin{array}{c}\% \\
\text { category }\end{array}$ & $\begin{array}{c}\% \\
\text { total }\end{array}$ \\
\hline organic & 35 & 19.34 & 7.32 & farmers markets & 22 & 75.86 & 4.60 & good idea & 11 & 28.21 & 2.30 \\
\hline healthy & 31 & 17.13 & 6.49 & $\begin{array}{l}\text { locally sold produce, } \\
\text { local opportunity to grow }\end{array}$ & 2 & 6.90 & 0.42 & $\begin{array}{l}\text { not used } \\
\text { enough }\end{array}$ & 5 & 12.82 & 1.05 \\
\hline $\begin{array}{l}\text { produce such as } \\
\text { tomatoes, cabbage }\end{array}$ & 24 & 13.26 & 5.02 & or purchase produce & & & & $\begin{array}{l}\text { not important } \\
\text { to me }\end{array}$ & 4 & 10.26 & 0.84 \\
\hline Freshness & 23 & 12.71 & 4.81 & $\begin{array}{l}\text { not located at grocery } \\
\text { stores }\end{array}$ & 2 & 6.90 & 0.42 & $\begin{array}{l}\text { cities, e.g., } \\
\text { New York, } \\
\text { Portland }\end{array}$ & 3 & 7.69 & 0.63 \\
\hline locally grown & 16 & 8.84 & 3.35 & CSAs & 1 & 3.45 & 0.21 & $\begin{array}{l}\text { boring, } \\
\text { wasted time }\end{array}$ & 3 & 7.69 & 0.63 \\
\hline food, e.g., meat, milk & 16 & 8.84 & 3.35 & farm boxes & 1 & 3.45 & 0.21 & $\begin{array}{l}\text { positive, } \\
\text { favorable }\end{array}$ & 3 & 7.69 & 0.63 \\
\hline $\begin{array}{l}\text { quality, e.g., more } \\
\text { appealing and } \\
\text { nutritious }\end{array}$ & 11 & 6.08 & 2.30 & $\begin{array}{l}\text { program at work to bring } \\
\text { fresh veggies }\end{array}$ & 1 & 3.45 & 0.21 & $\begin{array}{l}\text { don't know } \\
\text { much }\end{array}$ & 3 & 7.69 & 0.63 \\
\hline inconvenient & 7 & 3.87 & 1.46 & & & & & interesting & 1 & 2.56 & 0.21 \\
\hline $\begin{array}{l}\text { trusted and safe } \\
\text { products }\end{array}$ & 5 & 2.76 & 1.05 & & & & & $\begin{array}{l}\text { most } \\
\text { important }\end{array}$ & 1 & 2.56 & 0.21 \\
\hline natural & 3 & 1.66 & 0.63 & & & & & hobby & 1 & 2.56 & 0.21 \\
\hline convenient & 2 & 1.10 & 0.42 & & & & & the future & 1 & 2.56 & 0.21 \\
\hline variety & 2 & 1.10 & 0.42 & & & & & beautiful & 1 & 2.56 & 0.21 \\
\hline free & 1 & 0.55 & 0.21 & & & & & $\begin{array}{l}\text { specific } \\
\text { group }\end{array}$ & 1 & 2.56 & 0.21 \\
\hline GMO & 1 & 0.55 & 0.21 & & & & & thankful & 1 & 2.56 & 0.21 \\
\hline seasonal & 1 & 0.55 & 0.21 & & & & & & & & \\
\hline secure way & 1 & 0.55 & 0.21 & & & & & & & & \\
\hline short transport & 1 & 0.55 & 0.21 & & & & & & & & \\
\hline less preservatives & 1 & 0.55 & 0.21 & & & & & & & & \\
\hline
\end{tabular}

Note: \% category reflects the number of times a word/phrase is used relative to the total number of times of all words/phrases used within a content category. \% total reflects the number of times a word/phrase is used relative to the total number (sum) of all responses (=478). 
The category "point of sale" is dominated by the associations of farmers markets $(76 \%$ of category associations), locally sold produce ( $7 \%$ of category associations) and the fact that the produce will not be located at the grocery store (7\% of category associations). The category "other" is dominated by the associations with urban agriculture being a good idea ( $28 \%$ of category associations) and not being used enough (13\% of category associations), however, some state that it is important to them (10\% of category associations). Over all associations, organic and sustainability are associated most frequently with urban farms.

After discussing the psychological factor perception, we continue by describing the findings for the psychological factors that are included in the quantitative measurement, namely subjective knowledge and attitudes.

\section{Subjective knowledge related to urban agriculture}

As displayed in our conceptual framework we investigate the role of subjective knowledge regarding sustainability and urban agriculture (see table 3). Results show that participants feel most informed and knowledgeable regarding the general issue of sustainability of food supply with a mean above the midpoint of three. However, they do not feel informed about specific issues, such as community gardens and urban agriculture, as indicated by all means being below the midpoint of three. This leads to the conclusion that more education towards urban agriculture is needed because only if consumers feel knowledgeable they will be confident in choosing a certain outlet for their produce.

We then sum up the values for community gardens, CSA, urban gardens and urban agriculture into the subjective knowledge index to be used in the following econometric analysis. The knowledge index has a mean of $\mathrm{M}=9.7(\mathrm{SD}=3.9, \mathrm{Min}=4, \mathrm{Max}=20)$. The minimum of 4 and 
maximum of 20 suggest that some participants did not have any knowledge on the tested concepts, while others were very knowledgeable regarding all of them. Subjective knowledge on sustainability and urban agriculture are hypothesized to affect the intentions towards urban agriculture purchase and growing likelihood and are included as independent variables in the econometric analysis.

Table 3: Subjective knowledge towards sustainability and urban agriculture

\begin{tabular}{lcc}
\hline Feeling informed about... & Mean & SD \\
\hline Sustainability of food supply & 3.42 & 1.10 \\
Community gardens & 2.56 & 1.09 \\
Community Supported Agriculture (CSA) & 2.42 & 1.11 \\
Urban gardens & 2.36 & 1.10 \\
Urban agriculture & 2.32 & 1.09 \\
\hline
\end{tabular}

Scale from $1=$ no knowledge to 5=very knowledgeable.

\section{Attitudes towards urban agriculture}

Next, we identify consumer attitudes regarding urban agriculture. To do so, survey participants received 11 questions on specific and general urban agriculture related attitudes. Each item was evaluated individually on a five-point Likert-scale. Table 4 displays the mean and standard deviation. Results show that consumers mostly agree with the notions that urban farms help them to learn more about gardening, eat more organic food, and care about the environment, and that the food from urban farms is fresher. Overall, the mean for all statements is above the midpoint three indicating general agreement. 
Table 4: Attitudes towards urban agriculture

\begin{tabular}{lcc}
\hline & Mean & SD \\
\hline Urban gardens help me to learn more about gardening & 3.84 & 0.82 \\
The food from urban gardens is fresher & 3.82 & 0.86 \\
Urban gardens allow me to eat more organic food & 3.76 & 0.84 \\
Urban gardens help me to care more about the environment & 3.75 & 0.87 \\
Because of urban gardens I feel better about where my food comes from & 3.74 & 0.91 \\
Urban gardens allow me to eat new kinds of food & 3.46 & 0.88 \\
Urban gardens allow me to eat more fruits and vegetables & 3.46 & 0.91 \\
The food from urban gardens tastes better & 3.45 & 0.80 \\
Urban gardens help me make new friends & 3.27 & 0.88 \\
Because of urban gardens I am more physically active & 3.19 & 0.93 \\
When going to urban gardens I spend less money on food & 3.08 & 0.85 \\
\hline
\end{tabular}

Scale from $1=$ completely disagree to $5=$ completely agree.

Afterwards, the data were analyzed using exploratory factor analysis. Table 5 shows the rotated component matrix. The Kaiser-Meyer-Olkin criterion is 0.92 , which is considered to be marvelous. Through the factor analysis, the following factors were found to indicate consumer attitudes:

\section{Factor 1 (F1): Urban agriculture (UA) is better for me}

Contains generally positive items which express, for example, that urban agriculture helps to care more about the environment and to learn more about gardening. Furthermore, it allows to eat more organic food and food that is fresher. The Cronbach's alpha measures 0.88 , which is considered to be good.

\section{Factor 2 (F2): Urban agriculture (UA): new, fit, frugal}

Sums up the statements which express more specific reasons to go to urban farms, such as, 
spending less money on food, being more physically active, allowing to eat new kinds of food and making new friends. The Cronbach's alpha measures 0.70 , which is considered to be questionable.

Table 5: Attitudes Rotated Factor Loadings Matrix

\begin{tabular}{lcc}
\hline & $\begin{array}{c}\text { Factor1 } \\
\text { UA is better } \\
\text { for me }\end{array}$ & $\begin{array}{c}\text { Factor2 } \\
\text { UA: new, fit, } \\
\text { frugal }\end{array}$ \\
\hline Cronbach's alpha & 0.88 & 0.70 \\
\hline Urban gardens allow me to eat more fruits and vegetables & $\mathbf{0 . 6 5}$ & 0.37 \\
Urban gardens help me to care more about the environment & $\mathbf{0 . 7 1}$ & 0.24 \\
Urban gardens help me to learn more about gardening & $\mathbf{0 . 5 3}$ & 0.35 \\
Urban gardens allow me to eat more organic food & $\mathbf{0 . 8 2}$ & 0.15 \\
The food from urban gardens is fresher & $\mathbf{0 . 8 4}$ & 0.04 \\
The food from urban gardens tastes better & $\mathbf{0 . 6 5}$ & 0.24 \\
Because of urban gardens I feel better about where my food & & $\mathbf{0 . 7 9}$ \\
comes from & 0.01 & 0.23 \\
\hline When going to urban gardens I spend less money on food & 0.43 & $\mathbf{0 . 8 0}$ \\
Because of urban gardens I am more physically active & 0.48 & $\mathbf{0 . 5 2}$ \\
Urban gardens allow me to eat new kinds of food & 0.28 & $\mathbf{0 . 5 5}$ \\
Urban gardens help me make new friends & & $\mathbf{0 . 6 9}$ \\
\hline
\end{tabular}

\section{Attitudes towards reasons that prevent or encourage purchases from urban farms}

Then, we investigated attitudes towards reasons that prevent or encourage consumers to purchase produce from urban farms. Results in Table 6 show that freshness, health, taste and support of the environment and local economy are main reasons that encourage consumers to shop at urban farms. At the same time distance traveled, time commitment and too much work would prevent them from buying at urban farms.

Similar to the knowledge index we created two indexes by summing up those reasons with a median of four and higher into the index "encourage" and summing up those reasons with 
a median smaller than four into the index "prevent." Given that the number of items differs for the two indexes, the sum for each index is then divided by the respective number of the items. Table 6: Reasons that prevent or encourage purchase of produce from urban farms

\begin{tabular}{|c|c|c|c|c|}
\hline & Mean & Median & SD & Index \\
\hline Freshness & 4.20 & 4.00 & 0.84 & \multirow{7}{*}{ 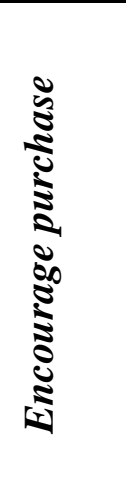 } \\
\hline Supporting the environment & 4.08 & 4.00 & 0.91 & \\
\hline Health & 4.04 & 4.00 & 0.97 & \\
\hline Supporting local economy & 4.00 & 4.00 & 0.96 & \\
\hline Taste & 3.85 & 4.00 & 0.94 & \\
\hline Food safety & 3.64 & 4.00 & 1.12 & \\
\hline Variety & 3.50 & 4.00 & 0.98 & \\
\hline Variety available & 3.45 & 3.00 & 1.04 & \multirow{6}{*}{ 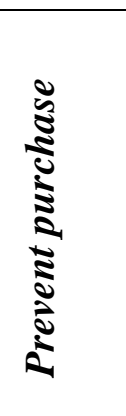 } \\
\hline Cost for food & 3.07 & 3.00 & 1.19 & \\
\hline Convenience & 3.02 & 3.00 & 1.23 & \\
\hline Distance traveled & 2.88 & 3.00 & 1.20 & \\
\hline Time commitment & 2.59 & 2.50 & 1.11 & \\
\hline Too much work & 2.39 & 2.00 & 0.97 & \\
\hline
\end{tabular}

Scale from $1=$ prevent to $5=$ encourage.

In the next step of the analysis, the factors and indexes are included in the econometric analysis to determine the impact of attitudes on the likelihood to purchase and grow food at urban farms. This tests the influence of psychological factors on intentions.

\section{Likelihood to purchase and grow produce from urban farms}

In our econometric analysis we use two variables as dependent variables: the likelihood to purchase from and grow produce at urban farms. We measure both on a seven-point scale from $1=$ very unlikely to $7=$ very likely. Please note that this is a hypothetical measure given that we did not account for consumers' actual behavior. Table 7 shows that $60 \%$ are likely, at least to 
some extent, to buy produce from urban farms, whereas about $18 \%$ are undecided and about onefifth is rather unlikely to shop at urban farms.

Table 7: Likelihood to purchase and grow produce at urban farms

\begin{tabular}{lrrrrrr}
\hline Likelihood to & \multicolumn{3}{c}{ Purchase } & \multicolumn{3}{c}{ Grow } \\
\cline { 2 - 7 } & Freq. & Percent & Cum. & Freq. & Percent & Cum. \\
\hline Very unlikely & 14 & 4.31 & 4.31 & 47 & 14.46 & 14.46 \\
Unlikely & 25 & 7.69 & 12.00 & 42 & 12.92 & 27.38 \\
Somewhat unlikely & 28 & 8.62 & 20.62 & 42 & 12.92 & 40.31 \\
Undecided & 59 & 18.15 & 38.77 & 50 & 15.38 & 55.69 \\
Somewhat likely & 83 & 25.54 & 64.31 & 64 & 19.69 & 75.38 \\
Likely & 77 & 23.69 & 88.00 & 48 & 14.77 & 90.15 \\
Very likely & 39 & 12.00 & 100.00 & 32 & 9.85 & 100.00 \\
\hline
\end{tabular}

Compared to this, $44 \%$ are likely, at least to some extent, to grow their own produce at urban farms, while $15 \%$ are undecided and nearly $40 \%$ do not think that they would consider growing produce themselves at urban farms. Table 8 shows a cross-tabulation of the two variables.

Results show that there is a correlation between buying and growing produce at urban farms.

Table 8: Cross-tabulation likelihood to purchase and grow produce from urban farms

\begin{tabular}{lrrrrrrrr}
\hline Count & \multicolumn{8}{c}{ Grow at urban farm } \\
\hline $\begin{array}{l}\text { Purchase at } \\
\text { urban farm }\end{array}$ & $\begin{array}{c}\text { Very } \\
\text { unlikely }\end{array}$ & Unlikely & $\begin{array}{c}\text { Somewhat } \\
\text { unlikely }\end{array}$ & Undecided & $\begin{array}{c}\text { Somewhat } \\
\text { likely }\end{array}$ & \multicolumn{2}{c}{$\begin{array}{c}\text { Likely } \\
\text { likely }\end{array}$} & Total \\
\hline $\begin{array}{l}\text { Very } \\
\text { unlikely }\end{array}$ & 12 & 0 & 0 & 0 & 2 & 0 & 0 & 14 \\
Unlikely & 9 & 9 & 5 & 1 & 0 & 1 & 0 & 25 \\
Somewhat & & & & & & & & \\
unlikely & 10 & 8 & 4 & 4 & 2 & 0 & 0 & 28 \\
Undecided & 9 & 6 & 8 & 18 & 16 & 2 & 0 & 59 \\
Somewhat & & & & & & & & \\
likely & 3 & 13 & 15 & 13 & 22 & 12 & 5 & 83 \\
Likely & 3 & 3 & 6 & 11 & 17 & 28 & 9 & 77 \\
Very likely & 1 & 3 & 4 & 3 & 5 & 5 & 18 & 39 \\
\hline Total & 47 & 42 & 42 & 50 & 64 & 48 & 32 & 325 \\
\hline
\end{tabular}


Those who are unlikely to grow their own produce are also unlikely to buy from urban farms, while those who would likely use urban farms as an outlet for fresh produce would also consider growing their own fruits and vegetables. These results lead us to consider a bivariate ordered probit model rather than two independent ordered probit models.

\section{Determinants of produce buying and growing likelihood related to urban farms}

In accordance with our conceptual framework, we finish the analysis by testing how psychological and personal factors influence intentions towards urban agriculture. Table 9 presents results from the bivariate ordered probit model, investigating the influence of subjective knowledge, attitudes, purchase frequency and socio-demographics on the likelihood to buy and grow produce at urban farms (two categorical dependent variables). First of all, results show that the correlation coefficient Rho measures 0.447 , indicating that the likelihood to purchase and to grow food at urban farms are positively correlated. This suggests that the more likely someone is to shop at the urban farm, the more likely (s)he would be to grow produce there. This result is also supported by the Wald test of independent equations.

Starting with the psychological factors, the findings show that those consumers who are more knowledgeable regarding sustainability in the food chain are more likely to buy produce at urban farms. This, however, has no impact on growing produce at urban farms. Furthermore, the urban agriculture knowledge index is significant and positive suggesting the more knowledgeable consumers feel toward urban agriculture, the more likely they are to buy and grow produce at urban farms.

With regards to consumers' attitudes results show that a generally favorable attitude toward urban farms (F1, e.g., urban agriculture increases produce consumption, helps to care 
about the environment) increases the likelihood of buying and growing produce at urban farms.

Those holding more specific attitudes towards urban agriculture (F2, e.g., urban agriculture increases physical activity and saves money) are more likely to participate in growing fruits and vegetables at urban farms. Furthermore, differences among the reasons that encourage or prevent participants from purchasing produce from an urban farm are observed. As one would expect, the reasons that encourage purchase at urban farms indeed increase the likelihood to do so.

Nevertheless, those that are believed to prevent purchase from urban farms have a significant and positive effect on growing produce at urban farms.

Table 9: Determinants of buying and growing likelihood at urban farms

\begin{tabular}{|c|c|c|c|c|c|c|}
\hline \multirow{3}{*}{$\begin{array}{l}\text { Bivariate ordered probit } \\
\text { Subj. knowledge sustainability }\end{array}$} & \multicolumn{3}{|c|}{ Purchase likelihood } & \multicolumn{3}{|c|}{ Growing likelihood } \\
\hline & \multirow{2}{*}{$\begin{array}{r}\text { Coeff. } \\
0.112 *\end{array}$} & \multirow{2}{*}{$\begin{array}{l}\text { SE } \\
0.064\end{array}$} & \multicolumn{2}{|c|}{ z-value Coeff. } & \multirow{2}{*}{$\begin{array}{l}\text { SE } \\
0.065\end{array}$} & \multirow{2}{*}{$\begin{array}{r}\text { z-value } \\
0.720\end{array}$} \\
\hline & & & 1.740 & 0.047 & & \\
\hline UA Knowledge Index & $0.035 *$ & 0.018 & 1.960 & $0.069 * * *$ & 0.019 & 3.540 \\
\hline $\mathrm{F} 1: \mathrm{UA}$ is better for me & $0.435 * * *$ & 0.113 & 3.860 & $0.321 * * *$ & 0.120 & 2.660 \\
\hline F2: UA: new, fit, frugal & 0.153 & 0.096 & 1.580 & $0.422 * * *$ & 0.107 & 3.940 \\
\hline Encourage urban farm purchase index & $0.301 * *$ & 0.149 & 2.020 & -0.104 & 0.146 & -0.710 \\
\hline Prevent urban farm purchase index & 0.134 & 0.099 & 1.350 & $0.303 * * *$ & 0.102 & 2.970 \\
\hline Purchase frequency local & $0.140 * * *$ & 0.041 & 3.390 & $0.087 * *$ & 0.040 & 2.180 \\
\hline Gender (female) & 0.187 & 0.123 & 1.520 & $0.400 * * *$ & 0.121 & 3.310 \\
\hline Age & 0.012 & 0.014 & 0.850 & $0.026 * *$ & 0.011 & 2.470 \\
\hline Education & $0.165 * * *$ & 0.059 & 2.780 & $0.129 * *$ & 0.061 & 2.120 \\
\hline Athrho constant & $0.481 * * *$ & 0.083 & 5.790 & & & \\
\hline Log pseudolikelihood & -998.923 & & & & & \\
\hline Wald chi2(10) & 153.73 & & & & & \\
\hline Prob > chi 2 & 0.000 & & & & & \\
\hline
\end{tabular}

Note: $* * *, * *, * 1 \%, 5 \%, 10 \%$ significance level. SE=standard error. UA=urban agriculture. 
Looking at the personal factors, the more frequently consumers purchase local produce, the more likely they are to participate in urban farming, whether by shopping or by growing. The results on socio-demographics indicate that female and older consumers are more likely to grow their own produce. Also, as the level of education increases, the likelihood of consumers to do both, shop and grow produce at urban farms, increases as well.

\section{Discussion and Conclusion}

Urban agriculture offers direct access to local food, a promising opportunity, considering that local food continuous to be very popular. While early studies on local food found that consumers consider traditional food attributes such as price, appearance and quality to be more important than food origin (Kezis et al., 1984; Lockeretz, 1986), studies conducted in the 2000s displayed that consumers shifted their preferences toward local food, to the extent that they are now willing to pay a premium for it (Onozaka and Mcfadden, 2011; Willis, Carpio and Boys, 2016; Boys et al., 2014; Loureiro and Hine, 2002). The reasons for this shift are consumer beliefs that local food is fresher, of higher quality, tastes better, enhances the local economy and benefits the environment (Zepeda and Leviten-Reid, 2004; McGarry-Wolf et al. 2005; Schneider and Francis, 2005). Our findings support this with evidence that a positive perception of urban farms is based on food attributes that are part of product quality, such as, being safe to eat and being healthy. Overall, with regards to perception, we found that the three pillars of sustainability - economy, society and environment - all play an important part when it comes to consumer perception. However, we do note that the perceptions can be contradictory, for example, some consumers perceive produce from urban farms as more expensive (the majority) and others as cheaper (the minority). Furthermore, while these three categories contain each about $16 \%$ of the total associations each, the category that received the most associations and is the main driver of the 
perception of urban farms based on our content analysis is "Food \& Food Attributes" with 38\%. Finally, "Point of Sale" is determining consumer perception of urban farms. Looking at points of sale, farmers market in particular plays an important role. This is promising, given that those urban farms that sell directly to consumers could offer an alternative retail venue. The category "Food and Food Attributes," on the other hand, is dominated by the association of urban agriculture with organic. This suggests that consumers might assume that food from urban farms is produced organically, which seems to be supported by the fact that consumers purchase more local foods, instead of organic, since the late 1990s (Gallons et al., 1997; Food Processing Center, 2001). This could be understood as displaying a shift in preferences from organic to local foods, or that consumers assume that local food posseses characteristics of organic food (Naspetti and Bodini 2008; Onozaka et al. 2010), leading them to purchase more local. This phenomenon might warrant more in-depth research in the future.

In addition to consumer perception of urban agriculture, we investigated the role of subjective knowledge and attitudes as psychological factors that affect intentions towards urban agriculture. Descriptive findings show that consumers in general do not feel knowledgeable regarding urban agriculture, which could indicate that consumer education towards urban agriculture might increase the success of urban farms. This, for example, could be achieved via community centers where classes on nutrition and gardening for different ages could be offered. Results regarding attitudes indicate that consumers generally have a positive attitude toward urban agriculture and that the reasons that prevent them from using those farms as shopping outlets are mainly associated with cost and inconvenience. Indeed, it has to be acknowledged that cost and inconvenience are considerable obstacles for shoppers (e.g., McGarry-Wolf et al. 2005). However, given that prices at urban farms are not necessarily more expensive and, could rather 
be lower compared to other retail outlets, it might be that consumers misconceive some of the attributes associated with urban agriculture. This suggests that involved actors (e.g., the farmers) might want to provide information in this regard. Also, if convenience is seen as an obstacle, one could counteract this by highlighting that growing your own produce is associated with being outdoors, being active and becoming more involved and literate with food production. All of which are benefits to the individual given that most lifestyles nowadays are sedentary (Wakefield et al. 2007; Abraham et al., 2010; Caballero, 2007).

Our main econometric analysis investigated these findings further. Results show that several psychological and personal factors that influence the purchase likelihood are different from those that increase the growing likelihood, while others are similar. Our data indicate that consumers who feel more knowledgeable would go to urban farms to purchase produce and are also more likely to grow their own produce. One can argue that this might be because they are more likely to trust their decision on this produce outlet. In addition, attitudes play an important role in purchasing versus growing, showing that a positive attitude will increase urban farm participation in both directions (buying and growing) (F1), while a specific attitude (F2) will increase the chances of consumers deciding to grow produce themselves only. While this result contradicts Bamberg and Möser (2007) who find a weak linkage between attitudes and (proenvironmental) behavior, our results are similar to Feldmann and Hamm (2015) who conclude from their extensive literature review that local food purchase behavior can be predicted by attitudes. Similar to Feldmann and Hamm (2015) we find a strong relationship between intended behavior - as it relates to urban agriculture - and attitudes. Looking at the socio-demographic characteristics, the main result is that women are more likely to grow their own produce, and the same holds for an increase in age. This indicates that strategies that target male and younger 
consumers might be beneficial to increase the share of those who would consider to participate in urban agriculture.

Nevertheless, this study is not without limitations. For example, the interpretation of the associations with urban agriculture, i.e., content analysis, is subjective and hence, a different set of researchers might categorize some associations differently. Furthermore, direct questions in a survey, such as the ones used in this study, can lead to social desirability bias where participants answer questions in a way they believe will please the interviewer (Norwood and Lusk, 2011). However, past research shows that Web surveys lower this bias, particularly when questions ask sensitive information, as compared to computer-assisted telephone interviewing and interactive voice recognition (Kreuter et al., 2008). Thus we are reasonably confident that social desirability bias was minimized, given that we used an online survey. Future research could reduce this and obtain results that are potentially less biased using discrete choice experiments (Norwood and Lusk, 2011). Also, it needs to be kept in mind that the results are less generalizable given that the sample cannot be deemed as representative for the general population. Future studies could use broader, random samples to increase the representativeness of the answers.

Finally, we highlight that this survey is of hypothetical nature and does not test actual shopping behavior. Therefore, future research avenues might include estimation of consumer demand and preferences using revealed or (non-hypothetical) stated preference methods, such as choice experiments or auctions, to quantitatively determine the actual demand for produce from urban farms. Similarly, future studies that explore consumer willingness to pay for produce from urban farms would be beneficial, given that cost for produce from urban farms need to be matched by consumer willingness to pay for it. 
To conclude, knowing that approximately 54 percent of the world's population resides in urban areas and this proportion is projected to increase to 66 percent by year 2050 (United Nations ${ }^{5}$ ), it seems reasonable to assume that urban agriculture could reach a large number of consumers with and offer them the related benefits - not only the young consumer surveyed in this study. In fact, the number of people living in urban areas worldwide is expected to exceed six billion by the end of 2045 (World Bank, 2016), making it worthwhile to examine the idea of how the number of citizens that participate in urban agriculture, whether through purchasing or growing food, can be increased. Nevertheless, it seems vital to include young consumers when it comes to promoting sustainable consumption patterns (Bentley et al., 2004). The activities that are encouraging the next generations to consume responsibly will have to provide practical solutions that show that sustainable consumption is manageable and convenient in order to change the young consumers' behavior (Hume, 2010).

Overall, this study provides a promising outlook on the acceptance of urban agriculture. It also shows which behavioral components significantly influence the likelihood to purchase and grow produce at urban farms. This can be used to promote urban agriculture and increase participation. The psychological and personal factors examined in our research can be used to develop consumer-oriented targeted marketing and communication strategies to strengthen urban farms as viable sources for nutritious food. For example, given the importance of subjective knowledge, educational and promotional activities could be utilized to increase participation. In addition, since the analysis provides factors that prevent consumers from using urban farms as produce outlets, stakeholders could potentially use them in developing counteracting marketing strategies.

\footnotetext{
${ }^{5} \mathrm{http} / / /$ www.un.org/en/development/desa/news/population/world-urbanization-prospects-2014.html

${ }^{6} \mathrm{http}: / /$ data.worldbank.org/indicator/SP.URB.TOTL.IN.ZS
} 


\section{Acknowledgements.}

This work was supported by EASM-3: Collaborative Research: Physics-Based Predictive Modeling for Integrated Agricultural and Urban Applications, USDA-NIFA, Grant No. 201567003-23508 and EASM-3: Collaborative Research: Physics-Based Predictive Modeling for Integrated Agricultural and Urban Applications, NSF-MPS-DMS, Award Number: 1419593.

\section{References}

Abraham, A., Sommerhalder, K., \& Abel, T. (2010). Landscape and well-being: a scoping study on the health-promoting impact of outdoor environments. International Journal of Public Health, 55, 59-69.

Adams, D. C., \& Salois, M. J. (2010). Local versus organic: A turn in consumer preferences and willingness-to-pay. Renewable Agriculture and Food Systems, 25(04), 331-341.

Aertsens, J., Mondelaers, K., Verbeke, W., Buysse, J., \& Van Huylenbroeck, G. (2011). The influence of subjective and objective knowledge on attitude, motivations and consumption of organic food. British Food Journal, 113, 1353-1378.

Ajzen, I. (1991). The Theory of Planned Behavior. Organizational Behavior and Human Decision Processes, 50, 179-211.

Armstrong, D. (2000). A survey of community gardens in upstate New York: Implications for health promotion and community development. Health \& Place, 6(4), 319-327.

Bailkey, M., \& Nasr, J. (1999). From brownfields to greenfields: Producing food in North American cities. Community Food Security News. Fall, 2000, 6.

Bamberg, S. \& Möser, G. (2007). Twenty years after Hines, Hungerford, and Tomera: A new meta-analysis of psycho-social determinants of pro-environmental behaviour. Journal of Environmental Psychology, 27, 14-25.

Bentley, M., Fien, J., \& Neil, C. (2004). Sustainable consumption: Young Australians as agents of change. Canberra, Australia: National Youth Affairs Research Scheme. pp. 1-156.

Bonato, M. (1990): Wissensstrukturierung mittels Struktur-Lege-Techniken. Eine graphentheoretische Analyse von Wissensnetzen. Europäische Hochschulschriften, Peter Lang Verlag, Frankfurt am Main, Germany. 
Boys, K. A., Willis, D. B., \& Carpio, C. E. (2014). Consumer willingness to pay for organic and locally grown produce on dominica: Insights into the potential for an "Organic island". Environment, Development and Sustainability, 16(3), 595-617.

Brucks, M. (1985). The Effects of Product Class Knowledge on Information Search Behavior. Journal of Consumer Research, 12 (June), 1-16.

Bruhn, C., Vossen, P., Chapman, E., \& Vaupel, S. (1992). Consumer attitudes toward locally grown produce. California Agriculture, 46(4), 13-16.

Caballero, B. (2007). The Global Epidemic of Obesity: An Overview. Epidemiologic Reviews, $29,1-5$.

Carlson, Jay P., Vincent, Leslie H., Hardesty, David M., \& Bearden, William O. (2009). Objective and Subjective Knowledge Relationships: A Quantitative Analysis of Consumer Research Findings. Journal of Consumer Research, 35, 864-876.

Census (2015). Quick Facts. http://www.census.gov/quickfacts/table/PST045215/04, Accessed January 2017.

Costanigro, M., McFadden, D. T., Kroll, S., \& Nurse, G. (2011). An in-store valuation of local and organic apples: the role of social desirability. Agribusiness, 27(4), 465-477.

Darby, K., Batte, M. T., Ernst, S., \& Roe, B. (2008). Decomposing local: a conjoint analysis of locally produced foods. American Journal of Agricultural Economics, 90(2), 476-486.

Ellen, P. S. (1994). Do we know what we need to know? Objective and subjective knowledge effects on pro-ecological behaviors. Journal of Business Research, 30, 43-52.

ERS (2015). Trends in U.S. Local and Regional Food Systems. Report to Congress, Administrative Publication Number 068. https://www.ers.usda.gov/webdocs/publications/ap068/51173_ap068.pdf, accessed $1 / 8 / 2017$.

FAO (2007). Profitability and sustainability of urban and peri-urban agriculture. Agricultural management, marketing and finance occasional paper 19. ISBN 978-92-5-105881-7 ftp://ftp.fao.org/docrep/fao/010/a1471e/a1471e00.pdf, last accessed 1/20/2017.

Feldmann, C., \& Hamm, U. (2015). Consumers' perceptions and preferences for local food: A review. Food Quality and Preference, 40, 152-164.

Firth, C., Maye, D., \& Pearson, D. (2011). Developing “community” in community gardens. Local Environment, 16(6), 555-568. 
Flynn, L. R., \& Goldsmith, R. E. (1999). A Short, Reliable Measure of Subjective Knowledge. Journal of Business Research, 46, 57-66.

Food Processing Center (2001). Attracting Consumers With Locally Grown Products. Reports from the Food Processing Center, University of Nebraska-Lincoln. Paper 3. http://digitalcommons.unl.edu/fpcreports/3

FoodRisc (2017): Mixed methods research. What is it? http://resourcecentre.foodrisc.org/mixedmethods-research_185.html, last accessed 1/18/2017.

Gallons, J., Toensmeyer, U. C., Bacon, J. R., \& German, C. L. (1997). An analysis of consumer characteristics concerning direct marketing of fresh produce in Delaware: a case study. City, 28(1), 98-106.

Grebitus, C. (2008). Food quality from the consumer's perspective: An empirical analysis of perceived pork quality. Doctoral Thesis. Cuvillier Verlag, Göttingen, Germany.

Grebitus, C., Lusk, J., \& Nayga, R. (2013a). Effect of distance of transportation on willingness to pay for food. Ecological Economics, 88, 67-75.

Grebitus, C., Jensen, H.H., Roosen, J., \& Sebranek, J.G. (2013b). Fresh meat packaging: Consumer acceptance of modified atmosphere packaging including carbon monoxide. Journal of Food Protection, 76(1), 99-107.

Gryna, F.M. (1998). Market Research and Marketing. In: Juran, J.M, Godfrey, A.B., Hoogstoel, R.E. and E.G. Schilling (eds): Juran's Quality Handbook. McGraw-Hill, New York, USA, $5^{\text {th }}$ edition, 18.1 .

Hair Jr., J.F., Anderson, R.E., Tatham, R.L., \& Black, W.C. (1998). Multivariate Data Analysis. Prentice Hall, New Jersey, USA, $5^{\text {th }}$ edition.

Heaney, J. (2006). Generations X and Y's internet banking usage in Australia. Journal of Financial Services Marketing, 11(3): 196-210.

Howard, J.A., \& Sheth, J.N. (1969). A theory of buyer behavior. Journal of the American Statistical Association, January 1969, doi: 10.2307/2284311.

Hsia, H.J. (1988). Mass Communications Research Methods: A Step-by-Step Approach. J. Bryant (ed.): Communication Textbook Series. A.M. Rubin (advisor): Mass Communication. Lawrence Erlbaum Associates, Inc. Hillsdale, New Jersey, USA.

Hughes, D. W., \& Boys, K. A. (2015). What We Know and Don't Know About the Economic Development Benefits of Local Food Systems. Choices, 30(1). 
Hume, M. (2010). Compassion without action: Examining the young consumers consumption and attitude to sustainable consumption. Journal of World Business 45, 385-394.

James, J. S., Rickard, B. J., \& Rossman, W. J. (2009). Product differentiation and market segmentation in applesauce: Using a choice experiment to assess the value of organic, local, and nutrition attributes. Agricultural \& Resource Economics Review, 38(3), 357.

Kanwar, R., Olson, J.C., \& Sims, L.S. (1981). Toward Conceptualizing and Measuring Cognitive Structures. Advances in Consumer Research, 8, 122-127.

Kezis, A. S., Toensmeyer, U. C., King, F. R., Jack, R. L., \& Kerr, H. W. (1984). Consumer acceptance and preference for direct marketing in the Northeast. Journal of Food Distribution Research, 15(3).

Kim, J.-O., \& Mueller, C.W. (1978). Factor Analysis. Statistical Methods and Practical Issues. In: Uslaner, E.M. (ed.): Quantitative Applications in the Social Sciences. Sage University Paper 07-014. SAGE Publications, Newbury Park, UK.

Krajnc, D., \& Glavič, P. (2005). How to compare companies on relevant dimensions of sustainability. Ecological Economics, 55, 551-563.

Kreuter, F., Presser, S. \& Tourangeau, R. (2008). Social desirability bias in CATI, IVR, and WEB surveys. The effects of mode and question sensitivity. Public Opinion Quarterly, 72(5), 847-865.

Kroeber-Riel, W., \& Weinberg, P. (2003). Konsumentenverhalten. Verlag Franz Vahlen, München, Germany.

Lamnek, S. (1995): Qualitative Sozialforschung. Band 2: Methoden und Techniken. Weinheim Verlag, Germany, $3^{\text {rd }}$ edition.

Libman, K. (2007): Growing Youth Growing Food: How Vegetable Gardening Influences Young People's Food Consciousness and Eating Habits. Applied Environmental Education \& Communication, 6(1), 87-95.

Lockeretz, W. (1986). Urban consumers' attitudes towards locally grown produce. American Journal of Alternative Agriculture, 1(02), 83-88.

Loureiro, M. L., \& Hine, S. (2002). Discovering niche markets: A comparison of consumer willingness to pay for local (Colorado grown), organic, and GMO-free products. Journal of Agricultural and Applied Economics, 34(3), 477-488. 
McCrindle Research. (2007). Socially conscious or selfish and materialistic? http://www.mccrindle.com.au/ResearchSummaries/Socially-Conscious-or-selfish-andmaterialistic.pdf, accessed 1/8/2017.

McGarry-Wolf, M., Spittler, A., \& Ahern, J. (2005). A profile of farmers' market consumers and the perceived advantages of produce sold at farmers' markets. Journal of Food Distribution Research, 36(1), 192-201.

Meas, T., Hu, W., Batte, M. T., Woods, T. A., \& Ernst, S. (2014). Substitutes or Complements? Consumer Preference for Local and Organic Food Attributes. American Journal of Agricultural Economics, aau108.

Moorman, C., Diehl, K., Brinberg, D., \& Kidwell, B. (2004). Subjective Knowledge, Search Locations, and Consumer Choice. Journal of Consumer Research, 31, 673-680.

Naspetti, S., \& Bodini, A. (2008). Consumer Perception of Local and Organic Products: Substitution or Complementary Goods? The International Journal of Interdisciplinary Social Sciences, 3(2), 111-122.

National Research Center, Inc. (2006). Community Food Project Evaluation Toolkit. Community Food Security Coalition, Sponsor: USDA Community Food Projects Program. Third Edition.

Nilsson, E., Gärling, T., Marell, A. \& Nordvall, A.-C. (2015). Importance ratings of grocery store attributes. International Journal of Retail \& Distribution Management, 43(1), 6391.

Norwood, F.B., \& Lusk, J.L. (2011). Social Desirability Bias in Real, Hypothetical, and Inferred Valuation Experiments. American Journal of Agricultural Economics, 93, 528-534.

Olson, J.C. \& Muderrisoglu, A. (1979). The Stability of Responses Obtained by Free Elicitation: Implications for Measuring Attribute Salience and Memory Structures. Advances in Consumer Research, 6, 269-275.

Onozaka, Y., \& Mcfadden, D. T. (2011). Does local labeling complement or compete with other sustainable labels? A conjoint analysis of direct and joint values for fresh produce claim. American Journal of Agricultural Economics, 93(3), 693-706.

Onozaka, Y., Nurse, G., \& McFadden, D. T. (2010). Local food consumers: how motivations and perceptions translate to buying behavior. Choices, 25(1), 1-6. 
Orquin, J. L., \& Mueller Loose, S. (2013). Attention and choice: A review on eye movements in decision making. Acta Psychologica, 144 (1), 190-206.

Oude Ophuis, P.A.M., \& H.C. M. van Trijp (1995). Perceived quality: A market driven and consumer oriented approach. Food Quality and Preference, 6, 177-183.

Pan, Y., \& Zinkhan, G.M. (2006). Determinants of retail patronage: A meta-analytical perspective. Journal of Retailing, 82(3), 229-243.

Parasuraman, A. (1990). Marketing Research. Addison-Wesley, Reading, USA, $2^{\text {nd }}$ edition.

Peschel, A.O., Grebitus, C., Steiner, B., \& Veeman, M.M. (2016). How does consumer knowledge affect environmentally sustainable choices? Evidence from a cross-country latent class analysis of food labels. Appetite, 106, 78-91.

Raju, P. S., Lonial, S. C., \& Glynn Mangold, W. (1995). Differential Effects of Subjective Knowledge, Objective Knowledge, and Usage Experience on Decision Making: An Exploratory Investigation. Journal of Consumer Psychology, 4, 153-180.

Roininen, K., Arvola, A., \& Laehteenmaeki, L. (2006). Exploring consumers' perceptions of local food with two different qualitative techniques: Laddering and word association. Food Quality and Preference, 17, 20-30.

Sahoo, K., Sahoo, B., Choudhury, A.K., Sofi, N.Y., Kumar, R., \& Bhadoria, A.S. (2015). Childhood obesity: causes and consequences. Journal of Family Medicine and Primary Care, 4(2), 187-192.

Sajaia, Z. (n.d.). Maximum likelihood estimation of a bivariate ordered probit model: implementation and Monte Carlo simulations. The Stata Journal (yyyy), vv (ii), 1-18.

Schneider, M.L. \& Francis, C.A. (2005). Marketing locally produced foods: consumer and farmer opinions in Washington County, Nebraska. Renewable Agriculture and Food Systems 20(4), 252-260

Shapiro, B.P. (1970). The Effect of Price on Purchase Behavior. Working Paper, Boston: Harvard University. In: Olson, J.C. (1972): Cue Utilization of the Quality Perception Process: A Cognitive Model and An Empirical Test. Unpublished Doctoral Dissertation, Purdue University.

Smola, K.W., \& Sutton, C.D. (2002). Generational differences: Revisiting generational work values for the new millennium. Journal of Organizational Behavior, 23, 363-382. 
Steenkamp, J.-B. (1989). Product Quality: An Investigation into the Concept and how it is Perceived by Consumers. Van Gorcum, Assen/Maastricht, The Netherlands.

Stempel, G.H., III (1981). Content Analysis. In: Stempel, G.H., III and B.H. Westley (eds.): Research Methods in Mass Communication. Prentice-Hall, Inc., Englewood Cliffs, New Jersey, USA.

Surls, R., Feenstra, G., Golden, S., Galt, R., Hardesty, S., Napawan, C., \& Wilen, C. (2015). Gearing up to support urban farming in California: Preliminary results of a needs assessment. Renewable Agriculture and Food Systems, 30(01), 33-42.

Thilmany, D., Bond, C.A., \& Bond, J.K. (2008). Going local: exploring consumer behavior and motivations for direct food purchases. American Journal of Agricultural Economics 90(5), 1303-1309.

Trafimow, D., \& Finlay, K.A. (2002). The Prediction of Attitudes from Beliefs and Evaluations: The Logic of the Double Negative. British Journal of Social Psychology, 41, 77-86.

Trommsdorff, V. (2003). Konsumentenverhalten. Kohlhammer, Stuttgart, Germany.

USDA (2016a). USDA Unveils New 'Urban Agriculture Toolkit' for Urban Farmers and Agribusiness Entrepreneurs. Release No. 0099.16.

https://www.usda.gov/wps/portal/usda/usdamediafb?contentid=2016/04/0099.xml\&printa ble $=$ true $\&$ contentidonly $=$ true, accessed 1/8/2017.

van Kleef, E., van Trijp, H.C.M., \& Kleef, P.L. (2005). Consumer research in the early stages of new product development: a critical review of methods and techniques. Food Quality and Preference, 16, 181-201.

Wakefield, S., Yeudall, F., Taron, C., Reynolds, J. \& Skinner, A. (2007). Growing urban health: Community gardening in South-East Toronto. Health Promotion International, 22(2), 92101.

Warren, E., Hawkesworth, S., \& Knai, C. (2015). Investigating the association between urban agriculture and food security, dietary diversity, and nutritional status: A systematic literature Review. Food Policy, 53, 54-66.

Willis, D.B., Carpio, C. E., \& Boys, K.A. (2016). “Supporting Local Food System Development Through Food Price Premium Donations: A Policy Proposal. Journal of Agricultural and Applied Economics, 48(2), 192-227. 
Wimmer, R.D., \& Dominick, J.R. (1983). Mass Media Research. An Introduction. In: R. Hayden (ed.): Wadsworth Series in Mass Communication. Wadsworth Publishing Company, Belmont, California, USA.

Zepeda, L., \& Leviten-Reid, C. (2004). Consumers' views on local food. Journal of Food Distribution Research, 35(3), 1-6.

Zezza, A., \& Tasciotti, L. (2010). Urban agriculture, poverty, and food security: Empirical evidence from a sample of developing countries. Food policy, 35(4), 265-273. 